\title{
Nutritional requirements for germination and in vitro development of three Orchidaceceae species in the southern Brazilian Amazon ${ }^{(1)}$
}

\author{
VIVIANE LUIZA HUNHOFF(2), LAÍS ALVES LAGE(2), EDNAMAR GABRIELA PALÚ(2), \\ WILLIAN KRAUSE ${ }^{(2)}$, CELICE ALEXANDRE SILVA(2)*
}

\begin{abstract}
Tissue culture is an alternative form of producing healthy, vigorous and regular plants on a large scale. The purpose of this study was to evaluate the most efficient culture medium for in vitro plantlet germination and development of three Orchidaceae species. Seeds disinfested of three species were dispersed in distilled water and dripped into basic Murashige and Skoog (MS) medium. The experimental design was completely randomized in a factorial $3 \times 4$ (three species $\mathrm{x}$ four culture media), with 5 replications. Four treatments were established: (1) full-strength MS medium, with the full nutrient concentration (MSØ), (2) full-strength MS medium plus $0.3 \%$ activated charcoal (MSØ ACh), (3) half- strength MS medium ( $1 \frac{1}{2} \mathrm{MS}$ ) and (4) half- strength MS medium with $0.3 \%$ activated charcoal ( $1 \frac{1}{2}$ MS ACh). Germination was evaluated after 15, 20, 25, 30, and 60 days. The shoot height, leaf number and length, root number and length of plantlets of the three studied species were assessed. In A. variegata, $73 \%$ germinated after 60 days in $1 / 2$ MS ACh medium. In the same period, $100 \%$ of E. viparum and S. gloriosa seeds germinated in MSØ ACh medium. The plant height, leaf number and length, root number and length were significantly higher for the species A. variegata and E. viviparum in MSØ ACh medium. The culture media $1 / 2 \mathrm{MS}$ and MSØ with addition of activated charcoal favored in vitro germination for the three orchid species of this study.
\end{abstract}

Keywords: culture medium, orchids, tissue culture Aspasia variegata, Epidendrum viviparum, Schomburgkia gloriosa.

\section{RESUMO}

Requerimentos nutricionais para germinação e desenvolvimento in vitro de três espécies de Orchidaceae do sudoeste da Amazônia brasileira

A cultura de tecidos é aplicada como alternativa de produção de mudas sadias, vigorosas, uniformes e em larga escala. O objetivo deste estudo foi avaliar o meio de cultura mais eficiente para a germinação e desenvolvimento in vitro de plântulas de três espécies de Orchidaceae. Sementes desinfestadas das três espécies foram colocadas em água destilada e gotejadas em meio de cultura básico de Murashige and Skoog (MS). O desenho experimental foi completamente ao acaso em um fatorial 3 x 4 (três espécies x quatro meios de cultura) com cinco repetições. Constituído de quatro tratamentos, sendo: (1) meio MS com concentração total de nutrientes (MSØ), (2) meio MS com concentração total de nutrientes acrescido de $0,3 \%$ de carvão ativado (MSØ C.A), (3) meio MS com metade das concentrações de nutrientes (1/2 MS) e (4) meio MS com metade das concentrações de nutrientes, acrescido de $0,3 \%$ de carvão ativado (1/2 MS C.A). A avaliação da germinação foi realizada aos 15, 20, 25, 30 e 60 dias. Foram mensuradas altura da parte aérea, número e comprimento das folhas e número e comprimento de raízes de plântulas das três espécies estudadas. Em $A$. variegata verificou-se uma germinação de $73 \%$ aos 60 dias em meio $1 / 2$ MS C.A. E. viviparum e S. gloriosa obtiveram $100 \%$ de germinação para o mesmo período, em meio MS $\varnothing$ C.A. A altura da planta, número e comprimento de folhas, número e comprimento de raízes foram significativamente maiores para as espécies A. variegata e E. viviparum meio MSØ C.A. S. gloriosa obteve os menores índices de desenvolvimento de plântulas, para todas as características analisadas, independente do meio analisado. O meio de cultura 1 $12 \mathrm{MS}$ and MSØ com adição de carvão ativado favoreceu a germinação in vitro para as três espécies de orquídeas estudadas. Palavras-chave: cultura de tecidos, meio de cultura, orquídeas, Aspasia variegata, Epidendrum viviparum, Schomburgkia gloriosa.

\section{INTRODUCTION}

Different species of orchids are among the commercially most exploited plants, and can be used for ornamental, food, cosmetic and medicinal purposes. They are herbaceous, perennial plants with extremely varied shapes and colors, and sought worldwide by orchidologists and for floriculture (ROBERTS and DIXON, 2008).
The programs of breeding and reintroduction of species in their natural habitats have aroused the interest for native orchids with ornamental potential. This is particularly true for the species Aspasia variegata Lindl., Epidendrum viviparum Lindl. and Schomburgkia gloriosa Rchb.f, found in the state of Mato Grosso (KOCH and SILVA, 2012), due to their high ornamental value, robustness and potential for use in hybrid production, landscaping and commercial flower production. 
Under natural conditions, the germination of Orchidaceae seeds depends on a symbiosis with specific fungi for each species, resulting in low germination rates. Thus, the use of some biotechnological tools, such as tissue culture, makes the establishment of a large number of plants within a short cultivation period possible (SUZUKI and FERREIRA, 2007). The response of the orchid family to in vitro culture is mostly satisfactory, and the advantages over traditional propagation methods are numerous. For example, multiplication by mass cloning is fast and produces propagules with high levels of plant health, resulting in plants with appropriate characteristics for propagation (FIGUEIREDO et al., 2008). In this way, the tissue culture technique contributes to the preservation of the species and has a series of advantages, including the handling of a large number of plants within a short period under aseptic conditions (UNEMOTO et al., 2007).

The culture medium can optimize micropropagation protocols and is a key factor for the success of in vitro culture. This medium is composed of essential substances for tissue growth, according to the nutritional requirements of each species, and is largely responsible for the pattern of in vitro development (PACEK-BIENIEK et al., 2010). Thus, the culture medium should be chosen according to the study objective and the study species (PASQUAL, 2008). The most commonly used culture medium for micropropagation is MS, consisting of inorganic salts, carbohydrates, vitamins with sufficiently high nutrient concentrations for plant development, preventing nutrient excess or lack in the culture medium (MURASHIGE and SKOOG, 1962). Adding activated charcoal to the culture medium is one of the most widely used measures for in vitro plantlet propagation, growth and development, since charcoal is believed to have beneficial effects on some orchid species, e.g., increases in plant height and rooting (THOMAS, 2008; PACEKBIENIEK et al., 2010).

Doses of activated charcoal between 0.1 and $0.2 \%$ added to the culture media promoted the development of the aerial part of Miltonia flavescens (Lindl.) Lindl. (CHAPLA et al., 2009). While for Catasetum fimbriatum (C. Morren) Lindl., higher doses $0.5 \%$ were required to promote shoot development (MORALES et al., 2006).

The objective of this study was to evaluate the effect of concentration of MS culture medium and the use of activated charcoal on germination and development of in vitro plantlets of three native orchid species in the southern Brazilian Amazon.

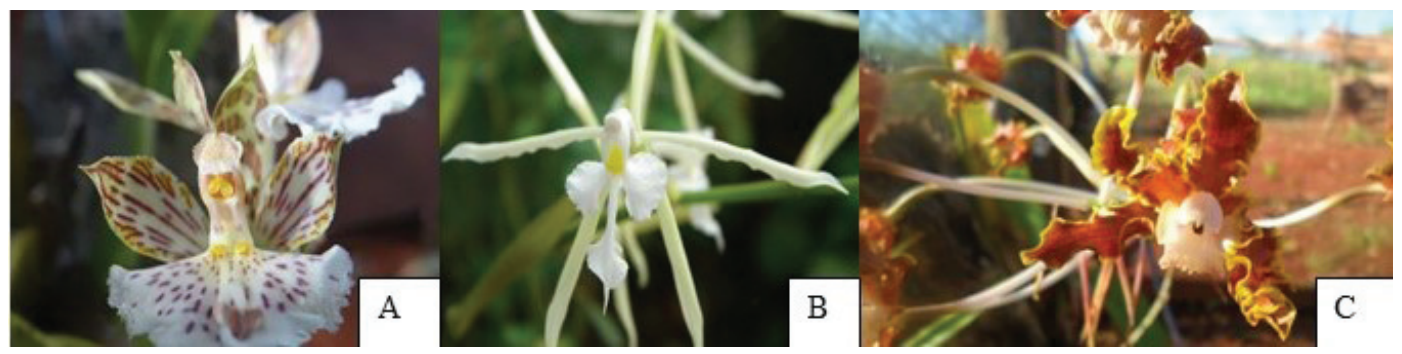

Figure 1. Flowers of Aspasia variegata (A), Epidendrum viviparum (B) and Schomburgkia gloriosa (C).

\section{MATERIAL AND METHODS}

Ripe fruit seeds of three orchid species (Figure 1) were collected, and the mature capsules were taken to the laboratory for plant and seed improvement.

The capsules were disinfected by immersion in $70 \%$ alcohol solution for $2 \mathrm{~min}$, rinsed with autoclaved distilled water and then with commercial sodium hypochlorite solution ( $2.5 \%$ of active chlorine) for $10 \mathrm{~min}$, and shaken by hand in a laminar flow hood. Then they were washed in $70 \%$ ethanol for $1 \mathrm{~min}$ and rinsed four times with autoclaved distilled water. The capsules were opened and the seeds removed. To the flasks with seeds, $10 \mathrm{~mL}$ of autoclaved distilled water was added, and $1 \mathrm{ml}$ of the solution with the seeds was syringed into the flasks containing $40 \mathrm{ml}$ of culture medium according to the treatments.

For germination of the three species (Aspasia variegata, Epidendrum viviparum and Schomburgkia gloriosa), the culture media used for seed inoculation were prepared with four different compositions, corresponding to the following four treatments: 1) full-strength MS medium, with full nutrient concentration (MSØ), (2) full-strength MS medium plus $0.3 \%$ activated charcoal (MSØ ACh), (3) half- strength MS medium ( $1 / 2 \mathrm{MS})$, and (4) half- strength MS medium plus $0.3 \%$ activated charcoal ( $1 / 2 \mathrm{MS}$ ACh). All media were enriched with $30 \mathrm{~g} \mathrm{~L}^{-1}$ sucrose, $7.0 \mathrm{~g} \mathrm{~L}^{-1}$ agar and the $\mathrm{pH}$ adjusted to $5.7 \pm 0.1$, and immediately sterilized by autoclaving $\left(121^{\circ} \mathrm{C}\right.$ at $\left.1.05 \mathrm{kgf} \mathrm{cm}^{-2}\right)$ for $20 \mathrm{~min}$.

The experimental design was completely randomized in a factorial $3 \times 4$ (three species $\mathrm{x}$ four culture media), with five replications (20 plantlets of each replication). After seeding, the flasks were sealed with plastic film and placed in a growth chamber at an average temperature of $25 \pm 2$ ${ }^{\circ} \mathrm{C}, 16 \mathrm{~h}$ photoperiod and light intensity of two fluorescent lamps of approximately $50 \mu \mathrm{mol} \mathrm{m} \mathrm{m}^{-2} \mathrm{~s}^{-1}$.

The germination percentage was assessed after 15, 20, 25,30 , and 60 days of cultivation. The germination speed index (GSI) was calculated as the sum of the number 
of germinated seeds per day divided by the number of days between sowing and germination, as described by MAGUIRE (1962).

$\mathrm{GSI}=(\mathrm{G} 1 / \mathrm{N} 1)+(\mathrm{G} 2 / \mathrm{N} 2)+(\mathrm{G} 3 / \mathrm{N} 3)+\ldots+(\mathrm{Gn} / \mathrm{Nn})$, where: GSI = germination speed index, G1, G2, G3, .., Gn $=$ number of plantlets counted in the first, second, third, and last evaluation; $\mathrm{N} 1, \mathrm{~N} 2, \mathrm{~N} 3, \ldots, \mathrm{Nn}=$ number of days from sowing to the first, second, third, and last evaluation. The seeds were considered germinated after seed breakage and primary leaf growth.

After 60 days, 20 plantlets of each replication were randomly evaluated to measure the plant height and the leaf and root number and length. The data were subjected to analysis of variance and the means compared by the
Tukey test at 5\%. The data of the above characteristics were transformed by. Statistical analyses were carried out with the statistical software SISVAR (FERREIRA, 2011).

\section{RESULTS AND DISCUSSION}

The beginning of germination of all studied species was characterized by seed swelling, due to water and nutrient uptake, followed by disruption of the seed integument and release of the embryo (Figure 2A). Subsequently, the development of protocorms (Figure 2B), protocorm growth (Figure 2C), and seedling development were observed (Figure 2D).

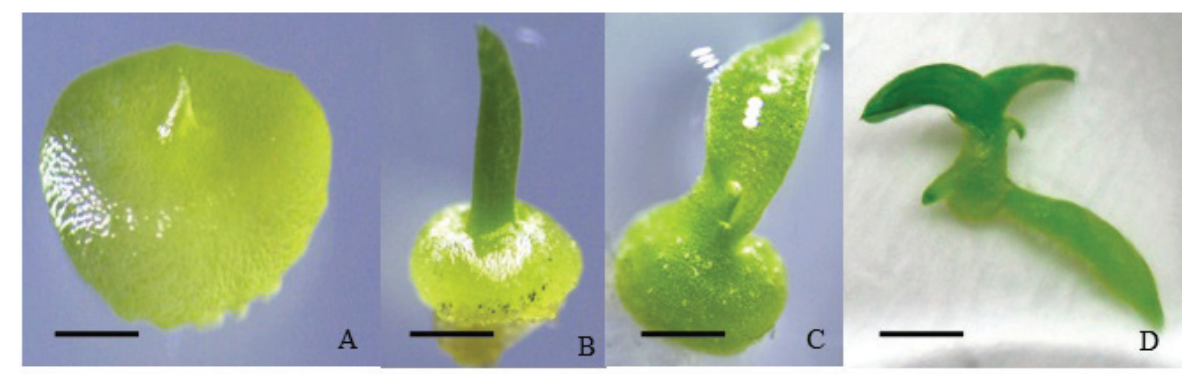

Figure 2. Germination stage of orchid seeds. (A) seed swelling and emergence, (B) development of protocorms, (C) formation and expansion of the protocorm leaflets, (D) emerging plantlet with leaflets and rhizoids. Figure 2 A-C Bars $=1 \mathrm{~mm}$; Figure $2 \mathrm{D}$ Bar $=1 \mathrm{~cm}$

According to Pridgeon et al. (1999) and Kraus et al. (2006), protocorms are a transitional structure following orchid seed germination, from which the beginning of the stem and root system is formed. This stage ends with the development of the first leaves, and from this moment onwards, the protocorm is characterized as seedling.

Structural evidence of seed germination, with seed disruption and growth of the primary leaflets, was first observed in Schomburgkia gloriosa (6.3\%) and Epidendrum viviparum (5.3\%) after 20 days of culture, and in Aspasia variegata (70\%) after 60 days (Table 1).
Other studies on ornamental Orchidaceae such as Cattleya walkeriana and Schomburgkia gloriosa also reported the onset of germination after 15 days of inoculation (SOUZA and JUNGHANS, 2006).

For the three species of this study (Schomburgkia gloriosa, Epidendrum viviparum and Aspasia variegata), the MS media with $0.3 \%$ activated charcoal (MSØ ACh) were the most appropriate for seed germination. The onset of germination of $A$. variegata seeds began after 60 days and was $27-30 \%$ lower than that of the other species (Table 1). 
Table 1. Seed germination percentage of Aspasia variegata, Epidendrum viviparum and Schomburgkia gloriosa (Orchidaceae), after 15, 20, 25, 30, and 60 days of culture, in comparison with the culture media with the compositions $1 / 2 \mathrm{MS}, \mathrm{MS} \varnothing, 1 / 2 \mathrm{MS} \mathrm{ACh}$, and MSØ ACh.

\begin{tabular}{|c|c|c|c|c|}
\hline Species & \multirow{2}{*}{ Days } & Aspasia variegata & Epidendrum viviparum & Schomburgkia gloriosa \\
\hline Culture medium & & \multicolumn{3}{|c|}{ Germination (\%) } \\
\hline \multirow{5}{*}{$1 / 2 \mathrm{MS}$} & 15 & 0.00 & 0.00 & 0.00 \\
\hline & 20 & 0.00 & 5.30 & 6.30 \\
\hline & 25 & 0.00 & 22.90 & 21.00 \\
\hline & 30 & 0.00 & 33.40 & 46.30 \\
\hline & 60 & 70.00 & 100.00 & 100.00 \\
\hline Means & & 14.00 & 32.32 & 34.72 \\
\hline CV $(\%)$ & & 31.30 & 20.14 & 40.61 \\
\hline \multirow{5}{*}{ MSØ } & 15 & 0.00 & 0.00 & 0.00 \\
\hline & 20 & 0.00 & 6.70 & 7.60 \\
\hline & 25 & 0.00 & 22.10 & 22.30 \\
\hline & 30 & 0.00 & 33.00 & 47.50 \\
\hline & 60 & 71.80 & 100.00 & 100.00 \\
\hline Means & & 14.36 & 32.36 & 35.48 \\
\hline CV $(\%)$ & & 32.10 & 39.95 & 40.36 \\
\hline \multirow{5}{*}{$1 / 2 \mathrm{MS}$ ACh. } & 15 & 0.00 & 0.00 & 0.00 \\
\hline & 20 & 0.00 & 7.00 & 11.30 \\
\hline & 25 & 0.00 & 23.50 & 29.70 \\
\hline & 30 & 0.00 & 36.90 & 49.00 \\
\hline & 60 & 73.00 & 100.00 & 100.00 \\
\hline Means & & 14.60 & 33.48 & 38.00 \\
\hline CV (\%) & & 32.64 & 39.86 & 39.34 \\
\hline \multirow{5}{*}{ MSØ ACh. } & 15 & 0.00 & 0.00 & 0.00 \\
\hline & 20 & 0.00 & 6.70 & 11.00 \\
\hline & 25 & 0.00 & 26.50 & 31.60 \\
\hline & 30 & 0.00 & 37.90 & 49.10 \\
\hline & 60 & 72.80 & 100.00 & 100.00 \\
\hline Means & & 14.56 & 34.22 & 38.34 \\
\hline CV (\%) & & 32.55 & 39.77 & 39.30 \\
\hline
\end{tabular}

The MS medium is widely used for the early plant development, for being rich in macro- and micronutrients and vitamins, at concentrations adjusted to the specific nutritional requirements for the development of each species (DEZAN et al., 2012). In the case of a lack of light energy and low $\mathrm{CO}_{2}$ concentration, the photosynthesis of in vitro cultivation can be hampered, creating a demand for an external supplementation of nutrients that are essential for plantlet germination and establishment in this type of cultivation (PASQUAL, 2008).

The choice of the culture medium is extremely important for the success of orchid seed germination (SUZUKI et al., 2009). The culture medium with full salt concentrations and with different nutrient compositions was best-suited for the montane grassland orchid Laelia cinnabarina Bateman ex Lindl. (STANCATO and FARIA, 1996). On the other hand, in studies with Oncidium baueri Lindl., Sorace et al. (2008) obtained satisfactory results with the development in vitro culture in MS medium with half the macro and micronutrient concentrations. The modification of the salt concentration in MS medium is an alternative for the adjustment of species-specific protocols for in vitro development, resulting in better plant development. Too low or even too high nutrient doses can be harmful for the plant and also raise production costs (CORDEIRO et al., 2011; CUNHA et al., 2011).

The germination speed index (GSI) of Schomburgkia gloriosa was higher, particularly in the medium supplemented with activated charcoal, followed by $E$. viviparum and $A$. variegata. Although the germination rates of $A$. variegata and E. viviparum were not significantly different in the studied media, the addition of $0.3 \%$ activated charcoal induced a 13.6 and $11.6 \%$ higher seed germination rate in $S$. gloriosa than the other MS $\varnothing$ and $1 / 2$ MS media, respectively, without this component (Figure 3). 


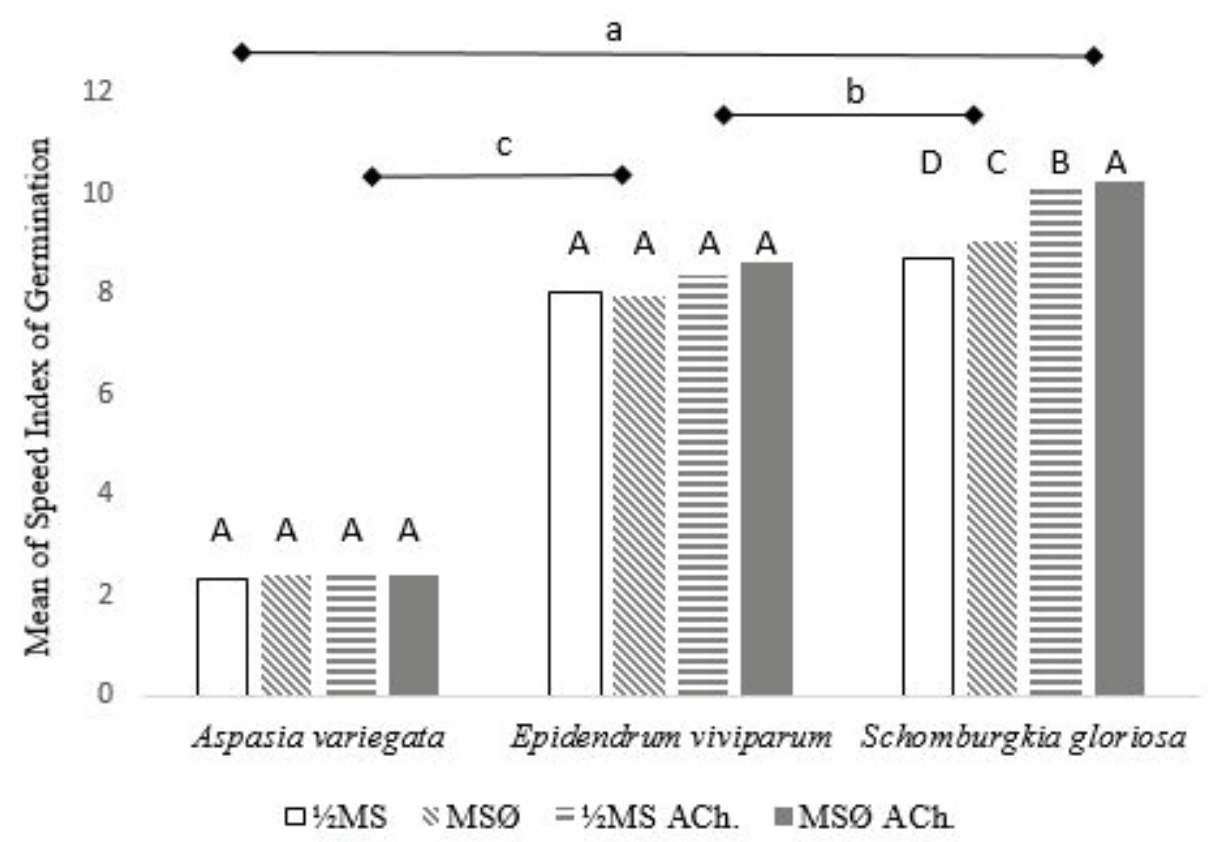

Figure 3. Speed Index of Germination (GSI) of three orchid species cultivated in vitro in different culture media. Means followed by the same letter in a column and capital letter in a row do not differ in the Tukey test at $5 \%$ probability.

Although the effects are species-specific, the addition of activated charcoal to the culture media commonly promotes some beneficial effects, e.g., the improvement of embryo development (CHAGAS et al., 2005) and of root growth (RIBEIRO et al., 2000). In addition, it influences the uptake of vitamins, inhibitory substances in the medium or toxic products released by explants, as well as the maintenance of $\mathrm{pH}$ and growth regulators (THOMAS, 2008).

In a study on Epidendrum ibaguense Kunth., Hossain (2008) tested the addition of activated charcoal to the medium and observed an increased number of germinated seeds, stimulation of early plantlet rooting and significant induction of protocorm formation with larger size (1.63 \pm 18 $\mathrm{mm})$ than the media without this component $(1.16 \pm 11 \mathrm{~mm})$.
Orchidaceae species have different responses to supplementation of nutrient media with charcoal addition. The MS medium with activated charcoal favored the development in height, leaf number and length and number of roots of Aspasia variegata and Epidendrum viviparum plantlets. In terms of plant height and root number, the performance of Schomburgkia gloriosa was identical in all tested culture media. The presence of activated charcoal favored the root length of A. variegata compared to other species. For $E$. viviparum on the other hand, the same characteristic was increased by the absence of this component. For $S$. gloriosa, the presence or absence of activated charcoal had no influence on root length (Table 2). 
Table 2. Mean values of plant height, leaf number, leaf length, root number and length of the orchids Aspasia variegata, Epidendrum viviparum and Schomburgkia gloriosa.

\begin{tabular}{|c|c|c|c|c|}
\hline \multirow{2}{*}{ Species } & \multicolumn{4}{|c|}{ Culture medium } \\
\hline & $1 / 2 \mathbf{M S}$ & MSØ & 1/2MS ACh. & MSØ ACh. \\
\hline & \multicolumn{4}{|c|}{ Plant height (cm) } \\
\hline Aspasia variegate & $1.90 \mathrm{aB}$ & $1.24 \mathrm{aC}$ & $1.95 \mathrm{aB}$ & $2.01 \mathrm{aA}$ \\
\hline Epidendrum viviparum & $0.98 \mathrm{bC}$ & $0.98 \mathrm{bC}$ & $1.67 \mathrm{bB}$ & $1.92 \mathrm{bA}$ \\
\hline \multirow[t]{2}{*}{ Schomburgkia gloriosa } & $0.53 \mathrm{cA}$ & $0.53 \mathrm{cA}$ & $0.53 \mathrm{cA}$ & $0.53 \mathrm{cA}$ \\
\hline & \multicolumn{4}{|c|}{ Leaf number (un) } \\
\hline Aspasia variegate & $1.43 \mathrm{cC}$ & $1.37 \mathrm{bC}$ & $3.15 \mathrm{aB}$ & $3.59 \mathrm{aA}$ \\
\hline Epidendrum viviparum & $1.83 \mathrm{aA}$ & $1.99 \mathrm{aA}$ & $1.92 \mathrm{bA}$ & $2.00 \mathrm{bA}$ \\
\hline \multirow[t]{2}{*}{ Schomburgkia gloriosa } & $1.61 \mathrm{bA}$ & $1.41 \mathrm{bA}$ & $1.39 \mathrm{cA}$ & $1.41 \mathrm{bA}$ \\
\hline & \multicolumn{4}{|c|}{ Leaf length $(\mathrm{cm})$} \\
\hline Aspasia variegate & $0.46 \mathrm{bC}$ & $0.43 \mathrm{bD}$ & $0.65 \mathrm{bB}$ & $0.69 \mathrm{bA}$ \\
\hline Epidendrum viviparum & $0.71 \mathrm{aB}$ & $0.71 \mathrm{aB}$ & $0.74 \mathrm{aB}$ & $1.03 \mathrm{aA}$ \\
\hline \multirow[t]{2}{*}{ Schomburgkia gloriosa } & $0.45 \mathrm{bA}$ & $0.45 \mathrm{bA}$ & $0.43 \mathrm{cA}$ & $0.45 \mathrm{bA}$ \\
\hline & \multicolumn{4}{|c|}{ Root number (un) } \\
\hline Aspasia variegate & $2.00 \mathrm{aB}$ & $1.33 \mathrm{aC}$ & $3.01 \mathrm{aA}$ & $3.16 \mathrm{aA}$ \\
\hline Epidendrum viviparum & $1.42 \mathrm{bB}$ & $1.37 \mathrm{aB}$ & $1.88 \mathrm{bA}$ & $1.89 \mathrm{bA}$ \\
\hline \multirow[t]{2}{*}{ Schomburgkia gloriosa } & $1.50 \mathrm{bA}$ & $1.51 \mathrm{aA}$ & $1.59 \mathrm{cA}$ & $1.59 \mathrm{cA}$ \\
\hline & \multicolumn{4}{|c|}{ Root length $(\mathrm{cm})$} \\
\hline Aspasia variegate & $0.64 \mathrm{bC}$ & $0.66 \mathrm{bC}$ & $1.07 \mathrm{aB}$ & $1.16 \mathrm{aA}$ \\
\hline Epidendrum viviparum & $1.10 \mathrm{aA}$ & $1.11 \mathrm{aA}$ & $0.80 \mathrm{bB}$ & $0.83 \mathrm{bB}$ \\
\hline Schomburgkia gloriosa & $0.53 \mathrm{cA}$ & $0.53 \mathrm{cA}$ & $0.52 \mathrm{cA}$ & $0.53 \mathrm{cA}$ \\
\hline
\end{tabular}

Means followed by the same letter in a column and capital letters in a row do not differ in the Tukey test at $5 \%$ probability.

Activated charcoal, aside from absorbing phenolic compounds, induces increased shoot formation and a greater number of roots, favoring plantlet support in the culture medium (LEDO et al., 2007).

A study on Cattleya bicolor Lindl. reported that apart from darkening the medium, activated charcoal is related to significant results concerning root growth of the plantlets (PRIZÃO et al., 2012). Dezan et al (2012), for example, found that the reduction in the salt concentration of MS culture medium was beneficial for the in vitro development of Schomburgkia gloriosa plantlets, as similarly found in this study with the same species.

\section{CONCLUSIONS}

The culture media $1 / 2$ MS and MS $\varnothing$ with addition of activated charcoal favors in vitro germination and the germination speed index (GSI) for the three orchid species of this study. Therefore, the development of the species Aspasia variegata, Epidendrum viviparum and
Schomburgkia gloriosa differed in response to activated charcoal in the culture medium.

\section{AUTHORS CONTRIBUTIONS}

V.L.H.: field analysis, data collection and analysis, manuscript preparation and review. L.A.L.: data collection and analysis, E.G.P.: data analysis and interpretation, manuscript critical review manuscript. W.K.: manuscript preparation and review. C.A.S.: manuscript preparation and review.

\section{REFERENCES}

CHAGAS, E.A.; PASQUAL M.; RAMOS J.D.; PIO, L.A.S.; DUTRA, L.F.; CAZETTA, J.O. Cultivo de embriões imaturos de citros em diferentes concentrações de carvão ativado e ácido giberélico. Ciência e Agrotecnologia, v.29, n.6, p.1125-1131, 2005. DOI: <http://dx.doi.org/10.1590/ S1413-70542005000600004> 
CHAPLA, P.I.; BESSON, J.C.F.; OLIVEIRA, L.K.; SILVA, J.M.; ROCHA, A.C.S.; STEFANELLO, S. pH, carvão ativado e agentes geleificantes do meio de cultura no crescimento in vitro de Miltonia flavescens Lindl. Plant Cell Culture \& Micropopagation, v.5, n.2, p.87-93, 2009.

CORDEIRO, G.M.; MORAES, C.P.; MASSARO, R.; CUNHA, T. Desenvolvimento in vitro de Cattleya amethystoglossa Lindley x (Cattleya dupreana x Laelia purpurata Lindleey) em diferentes meios de cultura. Revista Científica Eletrônica de Agronomia, v.18, n.1, p.22-28, 2011.

CUNHA, T.; CORDEIRO, G.M.; MASSARO, R.; DEZAN, L.F.; PEDROSO-DE-MORAES, C. Desenvolvimento in vitro de Laeliocattleya schilleriana Rolfe em meios de cultivo simplificados. Scientia Plena, v.7, n.6, p.1-5, 2011.

DEZAN, L.F.; CANASSA, F.; SOUZA-LEAL, T.; DIOGO, J. A.; MASSARO, R.; CORDEIRO, G.M.; PEDROSODE-MORAES, C. Crescimento in vitro de Schomburgkia gloriosa Lindl. em meio de cultivo simplificados. Idesia, v.30, n.2,p. 53-58, 2012. DOI: <http://dx.doi.org/10.4067/ S0718-34292012000200007>

FERREIRA, D.F. Sisvar: a computer statistical analysis system. Ciência e Agrotecnologia, v.35, n.6, p. 10391042, 2011. DOI: <10.1590/S1413-70542011000600001>

FIGUEIREDO, M.A.; PASQUAL, M.; ARAUJO, A.G.; JUNQUEIRA, K.P.; SANTOS, F.C.; RODRIGUES, V.A. Fontes de potássio no crescimento in vitro de plantas de orquídea Cattleya loddigesii. Ciência Rural, v.38, n.1, p. 255-257, 2008. DOI: <http://dx.doi.org/10.1590/S0103$84782008000100043>$

HOSSAIN, M.M. Asymbiotic seed germination and in vitro seedling development of Epidendrum ibaguense Kunth. (Orchidaceae). African Journal of Biotechnology, v.7, n.20, p.3614-3619, 2008.

KOCH, A.K.; SILVA, C.A. Orquídeas nativas de Mato Grosso. Cuiabá: Carline Caniato, 2012. 112p.

KRAUS, J.E.; KERBAUY, G.B.; MONTEIRO, W.R. Desenvolvimento de protocormos de Catasetum pileatum Rchb. F. in vitro: aspectos estruturais e conceituais. Hoehnea, v.33, n.2, p.177-184, 2006.

LEDO, A.S.; GOMES, K.K.P; BARBOZA, S.B.S.C.; VIEIRA, G.S.S.; TUPINAMBÁ, E.A.; ARAGÃO, W.M. Cultivo in vitro de embriões zigóticos e aclimatação de plântulas de coqueiro-anão. Pesquisa Agropecuária Brasileira, v.42, n.2, p.147-154, 2007.

MAGUIRE, J.D. Speed of germination - aid in selection and evaluation for seedling emergence and vigor. Crop Science, v.2, n.2, p.176-177, 1962.
MORALES, S.; MILANEZE, M.A.G.; MACHADO, M.F.P.S. Effect of activated charcoal for seedling development of Catasetum fimbriatum Lindley (Orchidaceae). Journal of Plant Science, v.1 n.4, p.388391, 2006.

MURASHIGE, T.; SKOOG, F. A reviser medium for rapid growth and bioassays with tobacco tissue cultures. Physiologia Plantarum,v.15, n.3, p. 473-497, 1962.

PACEK-BIENIEK, A.; DYDUCH-SIEMIŃSKA, M.; RUDAŚ, M. Influence of activated charcoal on seed germination and seedling development by the asymbiotic method in Zygostates grandiflora (Lindl.) Mansf. (Orchidaceae). Folia Horticulturae, v.22, n.2, p.45-50, 2010. DOI:<10.2478/fhort-2013-0158>

PASQUAL, M. Textos acadêmicos: meios de cultura. Lavras: FAEPE/UFLA, 2008. 25p.

PRIDGEON, A.M.; CRIBB, P.J.; CHASE, M.W.; RASMUSSEN, F.N. Genera Orchidacearum. New York: Oxford University Press, 1999. 197p.

PRIZÃO, E.C.; GONÇALVES, L.M.; GUTIERRES, M.A.M.; MANGOLIN, C.A.; MACHADO, M.F.P.S. Activated charcoal and graphite for the micropropagation of Cattleya bicolor Lindl. and orchid double-hybrid 'BLC Pastoral Innocence'. Acta Scientiarum Agronomy, v.34, n.2, p.157-161, 2012. DOI: <http://dx.doi.org/10.4025/ actasciagron.v34i2.12257>

RIBEIRO, V.G.; SANÁBIO, D.; SOUZA, C.N.; LOPES, P.S.N.; BOCARDO, M.R.; PASQUAL, M. Efeitos de ácido giberélico e carvão ativado no cultivo in vitro de Citrus limonia Osbeck x Poncirus trifoliata (L.) Raf. Pesquisa Agropecuária Brasileira, v.35, n.1, p.27- 30, 2000.

ROBERTS, D.L.; DIXON, K.W. Current Biology: Orchids, v.18, n., p.325-329, 2008.

SILVA, M.L.; CHAGAS, E.A.; FLORES, O.S.; ARAUJO, M.C.R.; COUCEIRO, M.A.;

SOUZA, A.S.; JUNGHANS, T.G. Introdução à micropropagação de plantas. Cruz das Almas: Embrapa Mandioca e Fruticultura Tropical, 2006. 152p.

STANCATO, G.C.; FARIA, R.T. In vitro growth and mineral nutrition of the lithophytic orchid Laelia cinnabarina Batem (Orchidaceae): effects of macro- and microelements. Lindleyana, v.11, n.1, p. 41-43, 1996.

SUZUKI, R.M.; FERREIRA, W.M. Introdução às técnicas de micropropagação de orquídeas. In: Barbosa, L.M.; Santos-Jr, N.A. (Eds.). A Botânica no Brasil: pesquisa, ensino e políticas públicas ambientais. São Paulo: Imprensa Oficial do Estado SP, 2007. p.655-659. 
SUZUKI, R.M.; MOREIRA, V.C.; NAKABASHI, M.; FERREIRA, W.M. Estudo da germinação e crescimento in vitro de Hadrolaelia tenebrosa (Rolfe) Chiron \& V.P. Castro (Orchidaceae), uma espécie da flora brasileira ameaçada de extinção. Hoehnea, v.36. n.4, p. 657-666, 2009. DOI: <http://dx.doi.org/10.1590/S2236-89062009000400006>
THOMAS, T.D. The role of activated charcoal in plant tissue culture. Biotechnology Advances, v.26, n.6, p.618631, 2008. DOI: <10.1016/j.biotechadv.2008.08.003>

UNEMOTO, L.K; FARIA, R. T.; VIEIRA, A.O.S; DALIO, R.J.D. Propagação in vitro de orquídeas brasileiras em meio de cultura simplificado. Revista Brasileira de Agrociência, v.13, p.267-269, 2007. 